\title{
Report
}

\section{XRF major element analyses of silicate rocks using 1:10 dilution ratio glass bead and a synthetically extended calibration curve method}

\author{
Toru Yamasaki
}

\begin{abstract}
Toru Yamasaki (2014) XRF major element analyses of silicate rocks using 1:10 dilution ratio glass bead and a synthetically extended calibration curve method. Bull. Geol. Surv. Japan, vol. 65 (7/8), p. 97-103, 1 figure, 5 tables.

Abstract: A high dilution ratio glass bead with a sample to flux ratio of 1:10 was prepared for a wide range of major element analyses using X-ray fluorescence spectrometer. Calibration curves were determined from 16 rock standards of the Geological Survey of Japan (GSJ) and 4 synthetic samples employing the software of the instrument. The precision of the calibration curves was sufficiently high, and the reproducibility was of adequate quality when compared to the 1:10 glass bead methods in other institutions laboratories. This method enables the measurement of igneous and metamorphic rocks that have extreme or anomalous bulk chemical compositions.
\end{abstract}

Keywords: X-ray fluorescence spectrometer (XRF), 1:10 glass bead method, calibration curve method, GSJ geochemical reference materials, USGS reference materials, GSJ-Lab, synthetic reference materials

\section{Introduction}

Whole rock major and trace element compositions of geologic rock samples are one of the most fundamental and important data that can be obtained in earth science studies. Recent advances in analytical methods and rapid increases in use of analytical instruments have enabled easy and precise analysis of whole rock sample compositions. In particular, the analytical method using X-ray Fluorescence Spectrometer (XRF) is the most common owing to several factors: the simple procedure involved in sample preparation, the relatively rapid analysis time, and the machine's stability. Since the latter half of 1990s, trace element XRF analysis using low dilution ratios (1:5 and 1:2) of glass beads have been carried out in many institutes (e.g. Kimura and Yamada, 1996; Kakubuchi et al., 1997; Takahashi and Shuto, 1997; Tanaka and Orihashi, 1997; Nagao et al., 1998). Such a method enabled the analysis of very trace elements such as rare-earth elements. Since this time, the analysis of major to trace elements using single glass beads has continued, although trace elements had been analyzed using pressed powder pellets before that time. In the 2000s, the rapid spread of Inductively Coupled Plasma Mass Spectrometry (ICP-MS) enabled the simultaneous measurement of ppb- and ppt-order multi-elements in larger numbers than that obtained with XRF. However, XRF analysis is still considered to be the best analytical method for use in major element analysis because of its accuracy and the ease of sample preparation.

In XRF analyses, it is necessary to correct the net count rates of $\mathrm{X}$-rays of the standard samples for inter-element effects (matrix effects), in order to convert X-ray intensity to concentration. The matrix effect increases with the increasing of concentration of elements, and can thus be reduced by dilution. The high dilution ratio method in this study therefore led to a reduction in the matrix effect. At present, therefore, the combined use of major element XRF analysis with a high dilution glass bead method and the application of trace element analysis using ICP-MS is commonly used to obtain whole rock data.

Analysis of whole rock samples using XRF commonly adopts the calibration curve method. In Japan, geochemical reference materials deployed by the Geological Survey of Japan (GSJ), and reference materials from the U.S. Geological Survey (USGS) are generally used as standard samples for use in constructing calibration curves. The composition of most igneous rocks are within the range of these standard samples. However, cumulus gabbroic rocks show a wide range of whole rock compositions in correspondence with the modal abundance of their constituent

AIST, Geological Survey of Japan, Institute of Geology and Geoinformation

Corresponding author: T.Yamasaki,Central 7,1-1-1 Higashi, Tsukuba, Ibaraki 305-8567, Japan. Email: t.yamasaki@aist.go.jp 
minerals. Consequently, on calibration curves, some gabbroic rocks have a composition that is out of the range of these standard samples, although gabbroic rocks have common lithologies. For instance, oxide gabbros, which are relatively common oceanic gabbros, have a composition of $30 \mathrm{wt} \% \mathrm{Fe}_{2} \mathrm{O}_{3}$ and $10 \mathrm{wt} \% \mathrm{TiO}_{2}$ due to the concentration of Fe-Ti oxides (e.g. Blackman et al., 2006). In addition, anomalously high-CaO ( $\sim 19 \mathrm{wt} \%)$ gabbroic cumulates and so-called felsic lithologies $\left(\sim 3 \mathrm{wt} \% \mathrm{P}_{2} \mathrm{O}_{5}\right)$ are also observed in oceanic gabbros (e.g. Dick et al., 1999). Similarly, cumulates in continental layered intrusions also show high- $\mathrm{TiO}_{2}$ ( $\sim 8 \mathrm{wt} \%)$, high- $\mathrm{Al}_{2} \mathrm{O}_{3}(\sim 27 \mathrm{wt} \%)$, and high- $\mathrm{Fe}_{2} \mathrm{O}_{3}(\sim 30 \mathrm{wt} \%)$ whole rock compositions in some cases (e.g. McBirney, 1989; Gleissner et al., 2010). Therefore, in order to analyze the whole rock composition of such samples using the calibration curve method, it is necessary to prepare a standard sample by adding a chemical reagent to a natural standard (e.g. Yoshizaki et al., 1996; Takahashi and Shuto, 1997; Yamamoto and Morishita, 1997; Yamasaki et al., 1999).

It is evident that if a method of analysis gains popularity, to guarantee the quality of data produced, it is necessary to report the analytical method and the precision and reproducibility of analytical data in individual laboratories or scientific research institutions. This paper thus reports an analytical procedure using the glass bead method with XRF (PANalytical Axios) at the GSJ-Lab in GSJ, the analytical results of the USGS reference materials, and the precision of those samples. It is noted that a precise routine analysis of whole rock major elements using XRF in the GSJ-Lab has previously been established (e.g. Togashi, 1989). However, using the method in this paper, it is possible to obtain the whole rock major element composition from $0.5 \mathrm{~g}$ of rock powder, and to enable a practically adequate quality of measurement for a wide range of compositions using synthetic standards.

\section{Standards and sample preparation}

\section{2-1. Standards}

Sixteen geochemical reference materials of the Igneous rock series provided by the GSJ were used to generate the calibration curves (JB-1 a, JB-2, JB-3, JA-1, JA-2, JA-3, JG-1 a, JG-2, JG-3, JR-1, JR-2, JGb-1, JGb-2, JP-1, JF-1 and JF-2). In addition to these samples, four synthetic samples were prepared by adding chemical reagents to the GSJ standards.

Synthetic standard samples were prepared using the following procedures. For the high contents standard of $\mathrm{Fe}_{2} \mathrm{O}_{3}$ and $\mathrm{TiO}_{2}$, $0.1545 \mathrm{~g}$ of iron oxide [III] (> 99.9, Wako Pure Chemical Industries Ltd.) and $0.0812 \mathrm{~g}$ of titanium oxide [IV] (> 99.0, Kanto Chemical Co. Ltd.) were added to $0.2641 \mathrm{~g}$ of JGb-1. For the high contents standard of $\mathrm{MnO}$ and $\mathrm{P}_{2} \mathrm{O}_{5}, 0.0283 \mathrm{~g}$ of manganese
Table. 1 Compositions of stnthetic standard materials.

\begin{tabular}{lcccc}
\hline & 1 & 2 & 3 & 4 \\
\hline $\mathrm{wt}^{2} \%$ & & & & \\
\hline $\mathrm{SiO}_{2}$ & 23.25 & 46.23 & 22.30 & 90.93 \\
$\mathrm{TiO}_{2}$ & 17.10 & 1.14 & 0.27 & 0.02 \\
$\mathrm{Al}_{2} \mathrm{O}_{3}$ & 9.31 & 13.01 & 41.33 & 5.03 \\
$\mathrm{Fe}_{2} \mathrm{O}_{3} *$ & 38.93 & 8.16 & 3.21 & 0.39 \\
$\mathrm{MnO}$ & 0.10 & 5.70 & 0.06 & 0.01 \\
$\mathrm{MgO}$ & 4.18 & 7.36 & 2.97 & 0.01 \\
$\mathrm{CaO}$ & 6.34 & 8.68 & 29.39 & 0.28 \\
$\mathrm{Na}_{2} \mathrm{O}$ & 0.64 & 2.38 & 0.44 & 1.43 \\
$\mathrm{~K}_{2} \mathrm{O}$ & 0.13 & 1.19 & 0.03 & 1.90 \\
$\mathrm{P}_{2} \mathrm{O}_{5}$ & 0.03 & 6.14 & 0.01 & 0.00 \\
\hline Total & 100.00 & 100.00 & 100.00 & 100.00
\end{tabular}

1: High $\mathrm{TiO}_{2} \& \mathrm{Fe}_{2} \mathrm{O}_{3} *$, 2: High $\mathrm{MnO} \& \mathrm{P}_{2} \mathrm{O}_{5}$,

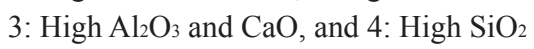

samples. $\mathrm{Fe}_{2} \mathrm{O}_{3}$ * denotes total $\mathrm{Fe}$ as $\mathrm{Fe}_{2} \mathrm{O}_{3}$.

oxide ( $>$ 99.0, Kanto Chemical Co. Ltd) and phosphorous oxide [V] (>98.0, Wako Pure Chemical Industries Ltd.) were added to $0.4498 \mathrm{~g}$ of JB- $1 \mathrm{~b}$. The standard of high contents in $\mathrm{Al}_{2} \mathrm{O}_{3}$ and $\mathrm{CaO}$, and the low content in $\mathrm{SiO}_{2}$ was prepared using the addition of $0.1503 \mathrm{~g}$ of aluminum oxide ( $>99.97$, Wako Pure Chemical Industries Ltd.) and $0.1131 \mathrm{~g}$ of calcium oxide (> 99.9, Wako Pure Chemical Industries Ltd.) to $0.2366 \mathrm{~g}$ of JGb-2. Silicon dioxide (0.2997 g; >99.9, Wako Pure Chemical Industries Ltd.) was added to $0.2002 \mathrm{~g}$ of JG-2 as the highest $\mathrm{SiO}_{2}$ standard. Bulk compositions of the synthetic standards were recalculated using actual weight measurements. Recalculated compositions of synthetic standard materials are shown in Table 1.

\section{2-2. Sample Preparation}

Glass beads were prepared using the following methods. The alkali flux used in this study was a lithium tetraborate $\left(\mathrm{Li}_{2} \mathrm{~B}_{4} \mathrm{O}_{7}\right.$ : MERK Co. Ltd., Spectromelt A10,\#10783). The flux was ignited at $700^{\circ} \mathrm{C}$ for $2 \mathrm{~h}$ prior to weighing, and cooled in a desiccator. Standard samples were then weighed in a ceramic crucible and ignited in a muffle furnace for $2 \mathrm{~h}$ at $900^{\circ} \mathrm{C}$.

Glass beads were prepared by mixing $0.5 \mathrm{~g}$ of powdered rock sample, or a mixture of rock sample and a chemical reagent(s), and $5.0 \mathrm{~g}$ of the flux (10 times the amount of the standard powder sample). The mixture was put into a platinum crucible $(95 \%$ Pt-5\% Au alloy) and two drops of lithium bromide aqueous solution $\left(\mathrm{LiBrH}_{2} \mathrm{O}: \mathrm{H}_{2} \mathrm{O}=1: 1\right)$ were added as exfoliation agent. Fusing and agitation were carried out with an automated high frequency bead sampler (Tokyo Kagaku Co. Ltd. TK-4500); at $120 \mathrm{~s}$ prefusion $\left(\sim 1070^{\circ} \mathrm{C}\right), 180 \mathrm{~s}$ fusion $\left(\sim 1070^{\circ} \mathrm{C}\right)$, and $180 \mathrm{~s}$ agitation. 
Table 2 Analytical conditions.

\begin{tabular}{|c|c|c|c|c|c|c|c|c|c|c|c|c|c|c|}
\hline \multirow[t]{2}{*}{ Element } & \multirow[t]{2}{*}{ Line } & \multicolumn{3}{|c|}{ Angle $(2 \theta)$} & \multirow[t]{2}{*}{ Target } & \multirow[t]{2}{*}{ Filter } & \multirow[t]{2}{*}{ Crystal } & \multirow[t]{2}{*}{ Detector } & \multirow{2}{*}{$\begin{array}{c}\text { Collimator } \\
(\mathrm{mm})\end{array}$} & \multirow[t]{2}{*}{ PHA } & \multirow[t]{2}{*}{$\mathrm{kV}$} & \multicolumn{3}{|c|}{$\mathrm{mA}$ Counting time (sec) } \\
\hline & & peak & $\mathrm{BG} 1$ & BG2 & & & & & & & & & peak & $\mathrm{BG}$ \\
\hline $\mathrm{Si}$ & $\mathrm{K} \alpha$ & 109.047 & -2.202 & 2.300 & $\mathrm{Rh}$ & None & $\mathrm{PE}(002)$ & $\mathrm{PC}$ & 300 & $24-78$ & 50 & 50 & 40 & 40 \\
\hline $\mathrm{Ti}$ & $\mathrm{K} \alpha$ & 86.163 & -2.654 & 2.535 & $\mathrm{Rh}$ & None & PX10 & $\mathrm{PC}$ & 300 & $22-76$ & 50 & 50 & 40 & 40 \\
\hline Al & $\mathrm{K} \alpha$ & 144.842 & -3.901 & 2.697 & $\mathrm{Rh}$ & None & $P E(002)$ & PC & 300 & $33-73$ & 50 & 50 & 40 & 40 \\
\hline $\mathrm{Fe}$ & $\mathrm{K} \alpha$ & 57.514 & -2.221 & 2.271 & $\mathrm{Rh}$ & None & PX10 & Duplex & 300 & $6-77$ & 50 & 50 & 40 & 40 \\
\hline $\mathrm{Mn}$ & $\mathrm{K} \alpha$ & 62.980 & -2.241 & 1.803 & $\mathrm{Rh}$ & None & PX10 & Duplex & 300 & $34-69$ & 50 & 50 & 40 & 40 \\
\hline $\mathrm{Mg}$ & $\mathrm{K} \alpha$ & 22.962 & 5.838 & - & $\mathrm{Rh}$ & None & PX1 & $\mathrm{PC}$ & 700 & $21-78$ & 50 & 50 & 40 & 20 \\
\hline $\mathrm{Ca}$ & $\mathrm{K} \alpha$ & 113.136 & -4.064 & 3.469 & $\mathrm{Rh}$ & None & PX10 & $\mathrm{PC}$ & 300 & $30-70$ & 50 & 50 & 40 & 40 \\
\hline $\mathrm{Na}$ & $\mathrm{K} \alpha$ & 27.753 & 2.950 & - & $\mathrm{Rh}$ & None & PX1 & $\mathrm{PC}$ & 700 & $27-80$ & 50 & 50 & 50 & 20 \\
\hline $\mathrm{K}$ & $\mathrm{K} \alpha$ & 136.721 & -5.765 & 5.385 & $\mathrm{Rh}$ & None & PX10 & PC & 300 & $29-74$ & 50 & 50 & 50 & 20 \\
\hline $\mathrm{P}$ & $\mathrm{K} \alpha$ & 140.913 & -5.235 & 4.981 & $\mathrm{Rh}$ & None & $\mathrm{Ge}(111)$ & PC & 300 & $20-77$ & 50 & 50 & 50 & 40 \\
\hline
\end{tabular}

PHA: Setting of pulse height analyzer.

\section{Analytical Method}

\section{3-1. Analytical Conditions}

XRF analysis was carried out using the PANalytical Axios at the GSJ-Lab in GSJ. A Rh anode X-ray tube was used and $\mathrm{K} \alpha$ line was measured for all elements. There was no obvious interfering spectrum for any major elements observed. Ip/Ib (net over background intensity, or signal/noise; $\mathrm{S} / \mathrm{N}$ ) ratios for all elements were adequately high, and X-ray intensities at both lower and higher angles against a peak position were used for background corrections, except for $\mathrm{Mg}$ and $\mathrm{Na}$. For $\mathrm{Mg}$ and $\mathrm{Na}$, one point at a higher angle against a peak position was used to avoid overlapping the slope of the adjacent peak. Positions of peaks, backgrounds, and analyzing crystals were settled, and the conditions for the highest X-ray intensity were obtained. Tube currents and voltages were $50 \mathrm{~mA}$ and $50 \mathrm{kV}$, respectively. Measurement time for all major elements per one sample was approximately $13 \mathrm{~min}$. Instrumental conditions for each element are shown in Table 2.

\section{3-2. Calibration and matrix corrections}

Calibration curves for each element using GSJ geochemical reference materials and synthetic standards with chemical reagent added to the GSJ standards are shown in Figure 1. Chemical compositions of GSJ standard Rocks Samples except for JB-1b are after Imai et al. (1995), and that of JB-1b are after Terashima et al. (1998). The calibration curves were calculated using software equipped with PANalytical Axios, and the linear functions were adopted for all elements. Matrix corrections were also carried out using software equipped with the instrument, and the de Jongh model was adopted. Table 3 shows the compositional range covered by calibration curves and their accuracy for each element. The accuracy of calibration curves in this study is at the same level as that reported using other instruments (e.g. Tsuchiya and Hasenaka, 1995; Takahashi and Shuto, 1997; Tanaka and Orihashi, 1997; Nagao et al., 1998).
Although the accuracy of $\mathrm{SiO}_{2}$ is relatively larger than that of other elements due to an extreme expansion of the compositional range in relation to synthetic standards, it is not considered to be a severe problem on a practical level.

\section{3-3. Detection limits and reproducibility}

For the calibration curve method, lower detection limits (LLD) are essentially defined by the lowest concentration of standard samples for each element. In the cases of $\mathrm{TiO}_{2}, \mathrm{Fe}_{2} \mathrm{O}_{3}, \mathrm{MnO}$, $\mathrm{MgO}, \mathrm{CaO}, \mathrm{Na}_{2} \mathrm{O}, \mathrm{K}_{2} \mathrm{O}$, and $\mathrm{P}_{2} \mathrm{O}_{5}$ used in this study however, the lowest content in the standards is $<0.1 \mathrm{wt} \%$. Therefore, in this case analytical reproducibility could have affected the quantitative analytical result.

Table 4 shows the average composition of analysis repeated 10 times for JB-1b and its standard deviation. Repeated continuous analysis was carried out in order to avoid instrumental drift and to examine counting error of the instrument. This shortterm reproducibility of essentially the same condition reveals the accuracy of the instrument in repeat analysis. The standard deviation of the analysis repeated 10 times was less than 0.04 $\mathrm{wt} \%$, particularly with elements of a lower concentration such as $\mathrm{TiO}_{2}, \mathrm{Fe}_{2} \mathrm{O}_{3}, \mathrm{MnO}, \mathrm{MgO}, \mathrm{CaO}, \mathrm{Na}_{2} \mathrm{O}, \mathrm{K}_{2} \mathrm{O}$, and $\mathrm{P}_{2} \mathrm{O}_{5}$, which were less than $0.01 \mathrm{wt} \%$. Those values were sufficiently smaller than the accuracy of the calibration curves, and thus in the cases of $\mathrm{TiO}_{2}, \mathrm{MnO}, \mathrm{MgO}, \mathrm{K}_{2} \mathrm{O}$ and $\mathrm{P}_{2} \mathrm{O}_{5}$, the values of accuracy of the calibration curves of those elements are substantially defined as LLD.

\section{Analytical results of reference materials and precision}

In order to estimate the precision of analytical results for unknown samples, six samples of the USGS reference materials were measured, in addition to the standard samples used for generating the calibration curves. The analytical results, refer- 

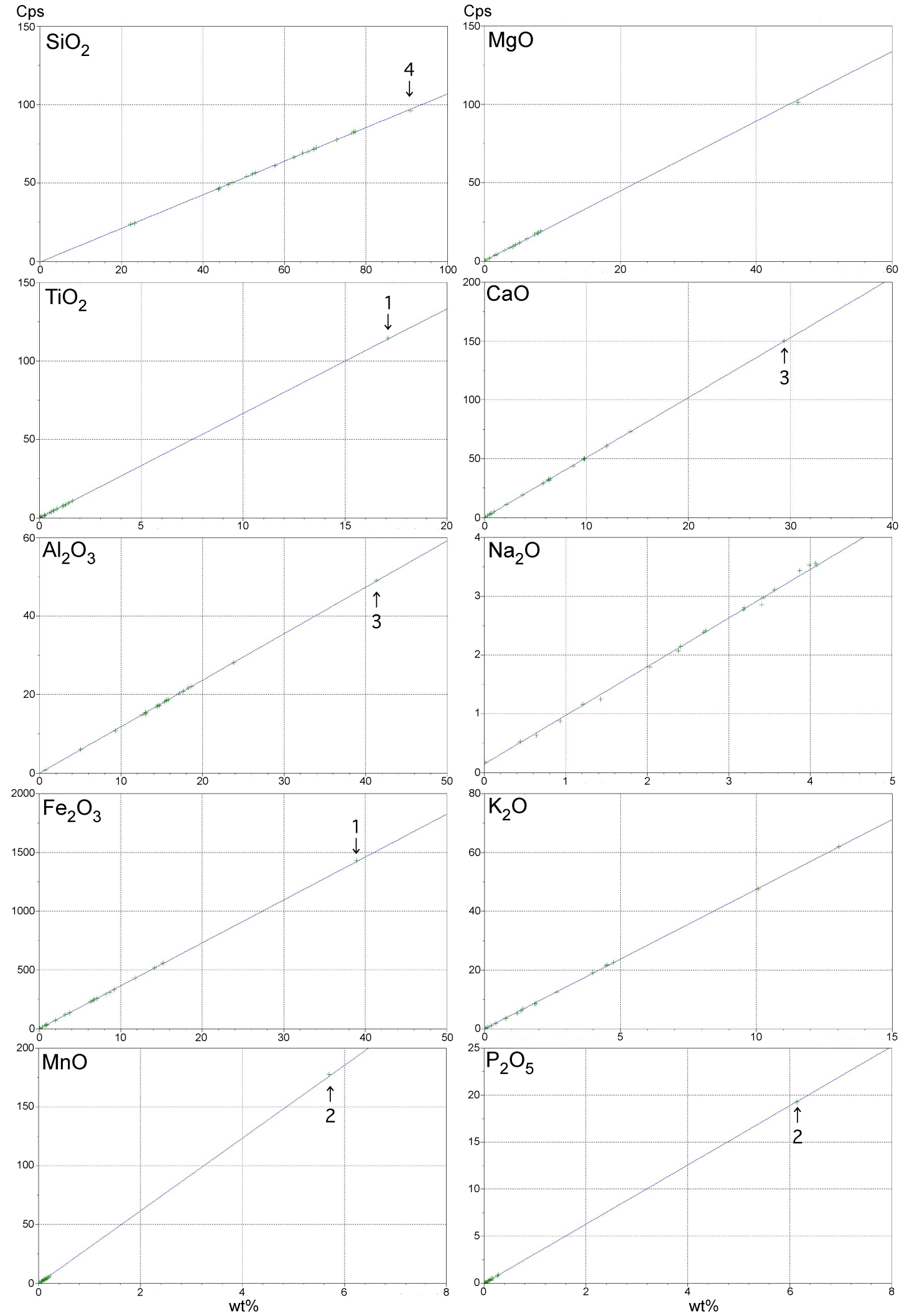

Fig. 1 Calibration curves for major element oxides. X-ray intensities after background and matrix corrections are plotted against concentration of each element. Arrows denote synthetic standard materials and the numbers correspond to numbers in Table 1. 
Table.3 Compositional range and accuracy of calibration curves.

\begin{tabular}{lccc}
\hline $\mathrm{wt}^{0}$ & Lower limit & Upper limit & Accuracy $(\mathrm{wt} \%)$ \\
\hline $\mathrm{SiO}_{2}$ & 23.25 & 90.93 & 0.36 \\
$\mathrm{TiO}_{2}$ & 0.01 & 17.10 & 0.02 \\
$\mathrm{Al}_{2} \mathrm{O}_{3}$ & 5.03 & 41.33 & 0.12 \\
$\mathrm{Fe}_{2} \mathrm{O}_{3} *$ & 0.06 & 38.93 & 0.10 \\
$\mathrm{MnO}$ & 0.00 & 5.70 & 0.01 \\
$\mathrm{MgO}$ & 0.00 & 46.12 & 0.19 \\
$\mathrm{CaO}$ & 0.09 & 29.39 & 0.06 \\
$\mathrm{Na}_{2} \mathrm{O}$ & 0.02 & 10.84 & 0.06 \\
$\mathrm{~K}_{2} \mathrm{O}$ & 0.00 & 13.03 & 0.04 \\
$\mathrm{P}_{2} \mathrm{O}_{5}$ & 0.00 & 6.14 & 0.01 \\
\hline
\end{tabular}

Accuracy $=\left\{\Sigma(\mathrm{Cm}-\mathrm{Cr})^{2} /(\mathrm{n}-2)\right\}^{1 / 2}, \mathrm{Cm}:$ measured value, $\mathrm{Cr}$ : recommended value and $\mathrm{n}$ : number of samples. $\mathrm{Fe}_{2} \mathrm{O}_{3}$ * denotes total $\mathrm{Fe}$ as $\mathrm{Fe}_{2} \mathrm{O}_{3}$.

ence values, and relative deviation are shown in Table 5. Most of the results show a relative deviation of less than $0.1 \mathrm{wt} \%$, and the largest relative deviation is $0.31 \mathrm{wt} \%$ at $\mathrm{SiO}_{2}$ of BIR-1. This value is smaller than the accuracy of the calibration curve, and within the standard deviation of reference value reported (Gladney and Roelandts, 1987; Table 5). Therefore precision of this method can be regarded as sufficient at a practical level.

\section{Summary}

An adequate quality of XRF major element analysis (PANalytical Axios) was obtained using a 1:10 dilution glass bead method with a $0.5 \mathrm{~g}$ sample of rock powder. Using the calibration curve method with 16 samples of GSJ geochemical reference materials and 4 synthetic samples prepared by addition of chemical reagents into GSJ standards enabled the quantitative analysis of a wide range of compositions $\left(\mathrm{SiO}_{2} 23.25-90.93 \mathrm{wt} \%\right.$, $\mathrm{TiO}_{2}$ 0.02-17.10 wt $\%, \mathrm{Al}_{2} \mathrm{O}_{3} 5.03-41.33 \mathrm{wt} \%, \mathrm{Fe}_{2} \mathrm{O}_{3}$ 0.06-38.93 wt\%, $\mathrm{MnO}$ 0.01-5.70 wt\%, MgO 0.19-46.12 wt \%, $\mathrm{CaO} 0.09-29.39$ wt $\%, \mathrm{Na}_{2} \mathrm{O}$ 0.06-10.84 wt $\%, \mathrm{~K}_{2} \mathrm{O}$ 0.04-13.03 wt $\%, \mathrm{P}_{2} \mathrm{O}_{5}$ 0.01$6.14 \mathrm{wt} \%)$.

\section{Acknowledgement}

I am grateful to M. Mikoshiba (Institute of Geology and Geoinformation, GSJ, AIST) for assistance in making glass bead and XRF operation. Also thank to T. Shimizu and M. Mikoshiba (Institute of Geology and Geoinformation, GSJ, AIST), and J. Maeda (Division of Natural History Sciences, Hokkaido University) for obtaining chemical reagents and standard samples.
Table.4 Reproducibility and precision of JB- $1 \mathrm{~b}$.

\begin{tabular}{cccccc}
\hline $\mathrm{wt}_{0} \%$ & R.V. & R.V.S.D. & Average $(\mathrm{n}=10)$ & S.D. & R.D. \\
\hline $\mathrm{SiO}_{2}$ & 52.226 & 0.11 & 52.565 & 0.036 & 0.339 \\
$\mathrm{TiO}_{2}$ & 1.288 & 0.03 & 1.266 & 0.003 & 0.022 \\
$\mathrm{Al}_{2} \mathrm{O}_{3}$ & 14.694 & 0.07 & 14.545 & 0.022 & 0.149 \\
$\mathrm{Fe}_{2} \mathrm{O}_{3} *$ & 9.217 & 0.07 & 9.121 & 0.004 & 0.096 \\
$\mathrm{MnO}$ & 0.150 & 0.001 & 0.140 & 0.000 & 0.011 \\
$\mathrm{MgO}$ & 8.318 & 0.06 & 8.586 & 0.009 & 0.268 \\
$\mathrm{CaO}$ & 9.810 & 0.06 & 9.773 & 0.007 & 0.036 \\
$\mathrm{Na}_{2} \mathrm{O}$ & 2.687 & 0.02 & 2.715 & 0.010 & 0.028 \\
$\mathrm{~K}_{2} \mathrm{O}$ & 1.349 & 0.01 & 1.311 & 0.003 & 0.038 \\
$\mathrm{P}_{2} \mathrm{O}_{5}$ & 0.262 & 0.005 & 0.261 & 0.001 & 0.001 \\
$\mathrm{Total}$ & 100.000 & - & 100.282 & - & - \\
\hline
\end{tabular}

R.V.: reference values by Terashima et al. (1998), R.V.S.D.: standard deviation for reference values $(n=20)$ by Terashima et al. (1998), S.D.: standard deviation, R.D.: relative deviation of averaged measuered values from reference values. $\mathrm{Fe}_{2} \mathrm{O}_{3}$ * denotes total $\mathrm{Fe}$ as $\mathrm{Fe}_{2} \mathrm{O}_{3}$.

\section{References}

Blackman, D.K., Ildefonse, B., John, B.E., Ohara, Y., Miller, D.J., MacLeod, C.J. and the Expedition 304/305 Scientists (2006) Proc. IODP, 304/305, College Station TX (Integrated Ocean Drilling Program Management International, Inc.). doi:10.2204/iodp.proc.304305.2006.

Dick, H.J.B., Natland, J.H., Miller, D.J., et al. (1999) Proc. ODP, Init. Repts., 176 [CD-ROM]. Available from: Ocean Drilling Program, Texas A\&M University, College Station, TX 77845-9547, U.S.A.

Gladney, E. S. and Roelandts, I. (1987) 1987 compilation of elemental concentration data for USGS BIR-1, DNC-1 and W-2. Geostand. Newsl., 12, 63-118.

Gladney, E. S. and Roelandts, I. (1988) 1987 compilation of elemental concentration data for USGS BHVO-1, MAG1, QLO-1, RGM-1, SCo-1, SDC-1, SGR-1 and STM-1. Geostand. Newsl., 12, 253-362.

Gladney, E. S., Jones, E. A., Nickell, E. J. and Roelandts, I. (1992) 1988 compilation of elemental concentration data for USGS AGV-1, GSP-1 and G-2. Geostand. Newsl., 16, 111-300.

Gleissner, P., Druppel, K. and Taubald, H. (2010) Magmatic evolution of anorthosites of the Kunene Intrusive Complex, NW Namibia: Evidence from oxygen isotope data and trace element zoning. Jour. Petrol., 51, 897-919.

Imai, N., Terashima, S., Itoh, S. and Ando, A. (1995) 1994 compilation of analytical data for minor and trace elements in seventeen GSJ geochemical reference samples, "igneous rock series". Geostand. Newsl., 19, 135-213.

Kakubuchi, S., Nagao, T., Yamada, Y., Kono, Y. and Shiraki, K. (1997) Quantification of rare-earth element in rock samples 
Table 5 Comparison with the analytical results of major elements and reference values of USGS reference materials.

\begin{tabular}{|c|c|c|c|c|c|c|c|c|c|c|c|c|}
\hline \multirow[b]{2}{*}{$w t \%$} & \multicolumn{4}{|c|}{ DNC-1 } & \multicolumn{4}{|c|}{ STM-1 } & \multicolumn{4}{|c|}{ BIR-1 } \\
\hline & R.V. & R.V.S.D. & M.V. & R.D. & R.V. & R.V.S.D. & M.V. & R.D. & R.V. & R.V.S.D. & M.V. & R.D. \\
\hline $\mathrm{SiO}_{2}$ & 47.32 & 0.64 & 47.05 & 0.27 & 60.75 & 0.49 & 60.62 & 0.13 & 47.65 & 0.51 & 47.34 & 0.31 \\
\hline $\mathrm{TiO}_{2}$ & 0.48 & 0.02 & 0.49 & 0.01 & 0.14 & 0.01 & 0.14 & 0.00 & 0.96 & 0.03 & 0.97 & 0.01 \\
\hline $\mathrm{Al}_{2} \mathrm{O}_{3}$ & 18.41 & 0.49 & 18.37 & 0.04 & 18.73 & 0.23 & 18.62 & 0.11 & 15.31 & 0.51 & 15.40 & 0.09 \\
\hline $\mathrm{Fe}_{2} \mathrm{O}_{3} *$ & 9.99 & 0.14 & 9.99 & 0.00 & 5.32 & 0.10 & 5.33 & 0.01 & 11.23 & 0.23 & 11.32 & 0.09 \\
\hline $\mathrm{MnO}$ & 0.15 & 0.01 & 0.14 & 0.01 & 0.22 & 0.02 & 0.21 & 0.01 & 0.17 & 0.01 & 0.16 & 0.01 \\
\hline $\mathrm{MgO}$ & 10.11 & 0.33 & 10.10 & 0.02 & 0.10 & 0.02 & 0.02 & 0.09 & 9.66 & 0.28 & 9.51 & 0.15 \\
\hline $\mathrm{CaO}$ & 11.34 & 0.22 & 11.36 & 0.02 & 1.11 & 0.06 & 1.16 & 0.05 & 13.21 & 0.29 & 13.22 & 0.02 \\
\hline $\mathrm{Na}_{2} \mathrm{O}$ & 1.88 & 0.09 & 1.89 & 0.01 & 9.11 & 0.20 & 9.34 & 0.23 & 1.75 & 0.11 & 1.78 & 0.04 \\
\hline $\mathrm{K}_{2} \mathrm{O}$ & 0.23 & 0.02 & 0.23 & 0.00 & 4.36 & 0.07 & 4.36 & 0.00 & 0.03 & 0.01 & 0.03 & 0.01 \\
\hline $\mathrm{P}_{2} \mathrm{O}_{5}$ & 0.09 & 0.02 & 0.07 & 0.01 & 0.16 & 0.01 & 0.16 & 0.00 & 0.05 & 0.03 & 0.02 & 0.02 \\
\hline \multirow[t]{2}{*}{ Total } & 100.00 & - & 99.68 & - & 100.00 & - & 99.94 & - & 100.00 & - & 99.76 & - \\
\hline & \multicolumn{4}{|c|}{ RGM-1 } & \multicolumn{4}{|c|}{ G-2 } & \multicolumn{4}{|c|}{$w-2$} \\
\hline wt\% & R.V. & R.V.S.D. & M.V. & R.D. & R.V. & R.V.S.D. & M.V. & R.D. & R.V. & R.V.S.D. & M.V. & R.D. \\
\hline $\mathrm{SiO}_{2}$ & 74.06 & 0.54 & 74.21 & 0.14 & 69.76 & 0.30 & 69.92 & 0.16 & 52.48 & 0.29 & 52.58 & 0.10 \\
\hline $\mathrm{TiO}_{2}$ & 0.27 & 0.03 & 0.25 & 0.02 & 0.48 & 0.03 & 0.49 & 0.00 & 1.06 & 0.01 & 1.08 & 0.02 \\
\hline $\mathrm{Al}_{2} \mathrm{O}_{3}$ & 13.90 & 0.19 & 13.90 & 0.00 & 15.53 & 0.32 & 15.46 & 0.06 & 15.39 & 0.16 & 15.32 & 0.07 \\
\hline $\mathrm{Fe}_{2} \mathrm{O}_{3} *$ & 1.88 & 0.06 & 1.91 & 0.03 & 2.68 & 0.10 & 2.65 & 0.04 & 10.79 & 0.21 & 10.87 & 0.08 \\
\hline $\mathrm{MnO}$ & 0.04 & 0.00 & 0.04 & 0.00 & 0.03 & 0.00 & 0.04 & 0.00 & 0.17 & 0.00 & 0.16 & 0.01 \\
\hline $\mathrm{MgO}$ & 0.26 & 0.03 & 0.29 & 0.03 & 0.76 & 0.03 & 0.72 & 0.04 & 6.35 & 0.06 & 6.37 & 0.02 \\
\hline $\mathrm{CaO}$ & 1.21 & 0.07 & 1.20 & 0.01 & 1.98 & 0.32 & 1.94 & 0.04 & 10.82 & 0.08 & 10.95 & 0.13 \\
\hline $\mathrm{Na}_{2} \mathrm{O}$ & 4.21 & 0.15 & 4.12 & 0.09 & 4.12 & 0.13 & 4.20 & 0.08 & 2.19 & 0.04 & 2.22 & 0.02 \\
\hline $\mathrm{K}_{2} \mathrm{O}$ & 4.41 & 0.10 & 4.41 & 0.00 & 4.52 & 0.13 & 4.52 & 0.00 & 0.62 & 0.01 & 0.63 & 0.01 \\
\hline $\mathrm{P}_{2} \mathrm{O}_{5}$ & 0.05 & 0.00 & 0.05 & 0.00 & 0.14 & 0.01 & 0.14 & 0.01 & 0.13 & 0.03 & 0.13 & 0.00 \\
\hline Total & 100.29 & - & 100.38 & $\begin{array}{lll}- & & \end{array}$ & 100.00 & - & 100.07 & - & 100.00 & - & 100.30 & - \\
\hline
\end{tabular}

R.V.: Reference values, R.V.S.D.: Standard deviation for reference values, M.V.: Measured values in this study, R.D.: relative deviation of measured values from reference values. Reference values and those standard deviation: DNC-1, BIR-1, W-2, Gladney and Roelandts (1987); STM-1, RGM-1, Gladney and Roelandts (1988); G-2, Gladney et al. (1992). $\mathrm{Fe}_{2} \mathrm{O}_{3}$ * denotes total $\mathrm{Fe}$ as $\mathrm{Fe}_{2} \mathrm{O}_{3}$.

using low-dilution ratio glass bead. Rept. Cent. Instr. Anal. Yamaguchi Univ., 5, 16-25 (in Japanese).

Kimura, J. and Yamada, Y. (1996) Evaluation of major and trace element XRF analyses using a flux to sample ratio of two to one glass beads. Jour. Min. Petrol. Econ. Geol., 91, 62-72.

McBirney, A. R. (1989) The Skaergaard Layered Series: I. Structure and average compositions. Jour. Petrol., 30, 363-397.

Nagao, T., Hase, Y., Nagamine, S., Kakubuchi, S. and Sakaguchi, K. (1998) "Sediment component" contributions to the magma genesis of the Hisatsu volcanic rocks, southern Kyushu: A case study of major, trace and rare earth elements analyses in rocks using low dilution glass bead with a dual target, Rh/W X-ray tube. The Rigaku-Denki Jour., 29, 34-46 (in Japanese).

Takahashi, T. and Shuto, K. (1997) Major and trace element analyses of silicate rocks using X-ray fluorescence spectrometer RIX3000. The Rigaku-Denki Jour., 28, 25-37 (in Japanese).

Tanaka, R. and Orihashi, Y. (1997) XRF analysis of major and trace elements for silicate rocks using low dilution ratio fused glass. HUEPS Tech. Rept., 2, 1-20.
Terashima, S., Taniguchi, M., Mikoshiba, M. and Imai, N. (1998) Preparation of two new GSJ geochemical reference materials: Basalt JB-1b and coal fly ash JCFA-1. Geostand. Newsl., 22, 113-117.

Togashi, S. (1989) XRF Analytical Report 1/89, Determination of major elements in igneous rocks using $\mathrm{Sc} / \mathrm{Mo}$ dual anode tube. GSJ Openfile Report, no. 132, Geol. Surv. Japan, AIST, 35p.

Tsuchiya, N. and Hasenaka, T. (1995) Major and trace element analyses of rock samples by X-ray fluorescence spectrometry using Rh anode tube. Ann. Rept. Fac. Edu., Univ. of Iwate, 55, 89-110 (in Japanese with English abstract).

Yamamoto, K. and Morishita, T. (1997) Preparation of standard composites for the trace element analysis by X-ray fluorescence. Jour. Geol. Soc. Japan, 103, 1037-1045 (in Japanese with English abstract).

Yamasaki, T., Owada, M., Imaoka, T. and Shiraki, K. (1999) Major and trace element analyses of rock samples by X-ray fluorescence spectrometry. Rept. Cent. Instr. Anal. Yamaguchi Univ., 7, 22-31 (in Japanese).

Yoshizaki, T., Tamura, Y., Sano, S., Hori, R., Komatsu, M. (1996) 
X-ray fluorescence analysis of major elements for silicate rocks. Mem. Fac. Sci., Ehime Univ., 2, 1-25 (in Japanese).
Received June 3, 2014

Accepted October 28, 2014

1:10 希釈合成試料ガラスビードを用いた蛍光 X 線分析装置による岩石中の主成分元素の定量分析

\author{
山崎 徹 \\ 要 旨
}

蛍光X線分析装置 $(\mathrm{XRF})$ による広範な組成範囲の全岩主成分化学組成分析のため,1:10希釈のガラスビードを調整した.検量線は 産業技術総合研究所岩石標準試料16試料と,それらに薬品を添加した合成試料4試料を用いてXRF搭載のソフトウェアにより作成し た、検量線の正確度及び再現性は1:10ガラスビードを用いた検量線法による一般的な組成範囲のXRF定量分析と比較して十分な精 度であったこの手法は,産業技術総合研究所岩石標準試料の組成範囲を超える極端な組成や特異的な組成の火成岩類及び変成 岩類の全岩主成分化学組成の分析を可能にする. 
